\title{
PARODY AND METAFICTIONALITY AS \\ Defamiliarization DeVICES IN MARTIN AMIS'S NOVEL MONEY: A SUICIDE NOTE
}

Loran Gami, University of Tirana, lorangami@gmail.com

Original scientific paper

DOI: 10.31902/fII.35.2021.3

\begin{abstract}
The article discusses the way defamiliarization is achieved in Martin Amis's novel Money: A Suicide Note (1984) through parody, the comical perspective, and the metafictional elements. In the introduction the concept of defamiliarization is briefly explained while the first section describes the use of parody in the novel. Amis's book parodies several literary techniques and is also a parody - as well as a critique - of the 1980s Britain and America, especially its consumerist ethos. By adopting a comical perspective, Amis creates a distancing effect between himself and the novel's protagonist, John Self. He is an unreliable and unlikable narrator and often his description borders on the grotesque, which also adds to the defamiliarization effect. The metafictional elements in the novel, discussed in the second section, are also important and they contribute to the distancing effect, by defamiliarizing what is commonly expected from a work of fiction. One of the most important metafictional (or self-referential) elements is the inclusion of the author as a character in the novel. This technique encourages the reader to re-evaluate the relation the author has with their own work, which is now seen from a defamiliarized perspective.
\end{abstract}

Keywords: defamiliarization, distancing, metafiction, parody, grotesque, consumerism, ethics

\section{Introduction}

In his influential article Art as Device, the Russian critic Viktor Shklovsky discusses the ostranenie that the authors achieve by their use and ordering of the literary devices. The term ostranenie has been variously translated as alienation, estrangement, enstrangement, or defamiliarizationin English. ${ }^{1}$ Shklovsky maintains that a literary work makes us adopt a fresh perspective on reality by presenting us with a

\footnotetext{
${ }^{1}$ Benjamin Sher, one of Shklovsky's translators into English states that the term defamiliarizationis misleading and he favors instead the term enstrangement (xviii-xix). In this article, however, the better-known term defamiliarization will be used.
} 
world which has become new, strange, unusual, non-familiar, and that is achieved by the special language and constructs of the literary text. The Brechtian technique of Verfremdungseffekt (the distancing effect) is similar to the Formalist concept of enstrangement. Even though Brecht used the term in drama, the concept is valid when analyzing prose works as well. The general thrust of the verfremdungseffekt is that acting should be such that the audiences should not identify with the action and the situation they see on stage. In line with his political agenda, Brecht wanted audiences to shake out of the complacency of bourgeois life. He regarded traditional drama as a theater in which the audiences and readers were not able to discern and understand the social problems because of the natural tendency to identify with the actors and events on stage. If, however, the action appears strange and even surprising to the audience, that will disrupt any illusion of reality and will make them think critically about the situation unfolding before their eyes. These ideas hark back to those of the English Romantic writers whose aim was to give "situations from common life [...] a certain coloring of imagination, whereby ordinary things should be presented to the mind in an unusual way" (Wordsworth, 595). The desire that Wordsworth and Coleridge felt in the Lyrical Ballads to shake readers from the "lethargy of custom" so as "to give the charm of novelty to things of everyday" (Coleridge) prefigure Shklovsky's and Brecht's ideas of defamiliarization and verfremdungseffekt. This article discusses the defamiliarization effect that the British writer Martin Amis achieves in his well-known novel Money: A Suicide Note, published in 1984. Several critics have pointed to the tendency Amis's fiction has to e(n)strange familiar things, thereby "affixing [the] label [...] Martian" (Tredell 44) to his technique ${ }^{2}$. Brian Finney writes that Amis achieves "unusual effects" with the aim of "defamiliariz[ing] our automatized response" (6), and Kiernan Ryan points to Amis's "redemptive defamiliarization" (216). John Sutherland, in a review of one of Amis's novels, states that "the quotidian and domestic props of life are rendered bafflingly alien and wonderful." (21) The present paper explores the most important elements and techniques that contribute to the defamiliarization effect in Amis's Money: A Suicide Note: the comical and ironic perspective the author takes towards the novel's protagonist, the parodic character of

\footnotetext{
${ }^{2}$ As Nicolas Tredell makes clear, the term "Martian" refers to a "technique associated above all with the poet Craig Raine and his poem 'A Martian Sends a Postcard Home' (1979), in which familiar objects and activities [...] are described in unfamiliar ways, as if seen with the estranging eyes of an alien visitor to earth." (44)
} 
the novel, as well as the metafictional (or self-referential) techniques, all of which will be discussed in the article.

\section{Defamiliarization through parody and the comical perspective}

The comical perspective Amis adopts towards the novel's protagonist is essential in understanding him and the novel as a whole. John Self, the main character, is rendered as a grotesque product of the consumerist 1980 s and of post-capitalist Western society - sexist, arrogant, hedonistic, and greedy. A partner in a London advertisement firm, Self embarks on a venture to produce his first Hollywood movie with the help of his producer, Fielding Goodney. He moves back and forth from England to America, trying to persuade various actors to fit in the roles that Goodney's script-writer has written. Self's life is chaotic and we see him frequenting pubs, stripclubs, and even blacking out several times after his late-night binges. All the time, with Goodney's assistance, he tries to advance the production of his movie, called Good Money, which seems to be totally unfeasible due to the script's unworkability, the actors' impossible demands and John Self's incompetence and listlessness, who carelessly signs checks under the guidance and encouragement of Goodney. Even though two (metafictional) characters, Martin Amis and Martina Twain, warn Self about the risks of his venture, he takes no heed until it is too late and he has lost all his money and is left penniless as the whole project turns out to have been a scheme. Without taking an overtly moralizing stance towards Self, Amis however adopts a comical perspective in portraying him. If a character is comically or parodically portrayed, it is difficult, if not outright impossible, for readers to identify with him. Readers would thus be estranged from that character and his actions and would regard them with a critical eye. Amis has created a quasi, or mock, picaresque novel, in which the hero, John Self, recounts his adventures in New York and London, involving visitations to pornography arcades, seedy bars, and even street fights. His job as an advertisement producer is also comically portrayed. This is how Self describes the way he and his firm's partners spend money:

We all seem to make lots of money. Man, do we seem to be coining it here [...] The car is free. The car is on the house. The house is on the mortgage. The mortgage is on the firm without interest. The interesting thing is: how long can this last? [...] It can't be legal, surely. You can't legally treat money in such a way. But we do. (78) 
The language Self uses throughout the novel is also sexist and this has led several critics to denounce Martin Amis as a sexist writer and one which supports the traditional patriarchal structures of male domination. Thus Sara Mills calls Amis a "quintessentially sexist writer" and his books (she refers to another book of Amis's, London Fields, which is, however, similar to Money in that respect) as wholly pervaded by sexism: "the female characters [seem] to be portrayed as stupid and as objects, usually sexual" and the "male characters also [seem] to be lifeless vehicles of an ideology of macho behaviour" $(207,208)$, while Laura Doan criticizes Amis for staying "within the patriarchal gender boundaries by upholding the pattern of dominance and submission" (qtd. in Parker 56). However, by exaggerating Self's sexist attitude and his macho behavior so that it borders on the grotesque, Amis is at the same time parodying it. He does indeed portray "the pattern of dominance and submission" but he defamiliarizes it through the use of parody and that of the unreliable narrator. Thus Self being an unreliable narrator "undermines [his] authority and perspective" and "characters like [...] [him] are vehicles for a critique of masculinity that exposes and undercuts patriarchal power" (Parker 60). By portraying him from a comical perspective and by making the narrator unreliable and unlikable, Amis has distanced himself from his protagonist. Discussing another of Amis's novels, Yellow Dog, Brian Crews asserts that "Amis clearly does distance himself from the character" and that he "is allowing this unsympathetic character to express the opposite view to that which we will be most likely to identify with" (654-655). In Money too, as Amis himself indicates through the fictitious Martin Amis, also a character in the novel, there is always a "distance between author and narrator," which "corresponds to the degree in which the author finds the narrator wicked, deluded, pitiful or ridiculous" (229). Self is all of these and, consequently, Amis has from the very beginning distanced himself from him.

Even though Self is sexist, reckless, insensitive, and even brutal, Amis has also portrayed him as "pitiful" and "ridiculous". For all his optimistic and macho talk about money, sex, drinking, and fights, insecurity and danger is always lurking underneath and in the end of the novel he declares:

Ever since I gave up my job and started waiting for the film to happen, I too have felt like a gap in between things. So how can you expect someone like me to deal with the day? [...] Tell me, please [...] I lie clueless in the cot until - until when? [...] Up, get out, do it now - now, now. Now! I drift, dither, grope, fumble 
[...] I look through the window [...] and I am simply stumped by this, dumbfounded. (145)

Amis has created a protagonist who, though self-confident, is delusional and throughout the novel readily believes that he is about to produce a successful movie, which will make him rich and pave his way for future lucrative Hollywood projects. In the end, this financial project turns out to have been a fraud to swindle Self out of his money, a scam created by his producer, Fielding Goodney, as a revenge on him. The comical character of the protagonist, which is made even more pronounced by his delusions and unwarranted self-confidence, contributes in alienating Self from the reader. Readers are presented with a protagonist who is unlikable - violent, boorish, a porn- and drug-addict, - and understandably they find it difficult to identify with such a man, thereby adding to the defamiliarization effect in the novel. It is likely that the portrayal of such anti-heroes in Amis's works as John Self in Money, Keith Talent in London Fields or Lionel Asbo in Lionel Asbo: State of England has led several critics to regard Amis as a writer to whom the "higher accolades of a residual humanist vocabulary", such as "the creation of 'living characters', humanity, maturity, seriousness, unity" (Tredell 7) cannot apply.

Parody is therefore an important element that adds to the novel's defamiliarizing effect. When discussing the narcissistic (metafictional) narrative fiction, which will be discussed in the second section, Linda Hutcheon observes that "[w]ith a technique not unlike that of Brecht's alienation effect, the parody and self-reflection [...] work to prevent the reader's identification with any character and to force a new, more active, thinking relationship upon him" (49). What is Amis parodying in Money? He parodies the first-person narration, one of the predominant perspectives especially in the bildungsromane and other traditional novels. Often in Money the authority of the first-person narration is undermined by the use of the metafictional techniques. The novel may read as a parody of the bildungsroman, the thriller, as well as of the picaresque novel recounting the protagonist's adventures in his trips to the States.

Money also reads as a parody of the whole 1980s America and the West, its post-capitalist and consumerist ethos. The world Amis describes is a world of flashy showbiz and advertisements, of people moving upward in the social scale, a world that Self is content to be part of. He thinks that by entering the world of the movies he will one day become rich, like other successful people in the film industry: 
The feeling in the office is that I am moving on to better things [...] I have been interviewed in Box Office [...] Peter Sennet did it. Freddie Giles and Ronnie Templeton did it. Jack Conn - he did it [...] They all have new houses, new wives, new tans, new rugs. ... [T] hey cruise the road-margined seas [...] Twice or three times a month they wing out for a long weekend on Thousand Island, a world that time forgot, down in the sea of joy. Everyone thinks that this will soon happen to me. (80)

Self's marketing-oriented and marketing-defined world is an electrifying world of potentialities, of huge possibilities and bright prospects, which are, nevertheless, illusory and self-deluding. If success happened to Sennet, Giles, Templeton, Conn (the significance of the last name is evident), it will surely come to Self too. By parodically exaggerating the language of marketing and advertisement, a language that emphasizes the inevitability of success, Amis has defamiliarized and at the same time criticized it. In an interview with John Haffenden, Amis comments on the effect television has on John Self: "I [...] mean him to be stupefied by having watched too much television - his life is without sustenance of any kind [...] He has this lazy non-effort response which is wished on you by television," an attitude Amis deplores and sees as the condition of modern life (qtd. in Tredell 63).

Success in Money is in the air and success is, of course, connected with money-making. As seen from the quoted passages and throughout the novel, the word money is omnipresent. Rather than tangible money, however, there is only spending, consuming and the promise of more money coming your way. Amis's novel parodies the postmodernist world and especially the Thatcherite decade (or Reagan's decade), the world of fast-food, addictions, money-making, and one of the salient features of this book is that it is narrated from the perspective of a protagonist who feels great about it and who until the last chapter boasts of being "addicted to the twentieth century" (89). It is a world of simulacrum and of illusion, a world in which man has even lost touch with his own nature:

I'm in the design department over at Silicone Valley [...] I move confidently among the technicians, the ideas-men [...] The heart boys doublecheck on my detailed specifications. I have a preparatory meeting with the rug people. We move on to the gene pool, the DNA programmers, the plasma bank [...] Eventually I produce my wallet, and silence falls. 'Okay, boys, now I want to make this absolutely clear. I'm paying top dollar 
and I expect the best [...] I want it blue, I want it royal, I want the best blood money can buy. (160)

Passages such as these present an exhilarating travesty of the enthusiastic and generally shallow language of television commercials and marketing specialists. Even the names of people, cars, and everything else in Money have a caricature-like, Dickensian, flavor in them and they verge on the grotesque. Thus Self drives a "powerful Fiasco" (the very name hints at Self's eventual downfall and ruin), actors bear such names as Lorne Guyland (who tries very hard to impress people with his macho behavior and sexual prowess), Self will take the airplane "Flight 666" and will be staying at "room 101", the spurious "moneymen" that would sponsor the movie bear such hilarious names as "Buck Specie" and "Sterling Dun", "Lira Cruzeiros" and "Valuta Groschen", cars of top managers are named "Tomahawks", "Hyenas", and "Boomerangs", the latter again referring to Self's delusional and unrealistic expectations about his grand business prospects and how all circumstances will turn against him and punish him in the end. Self's girlfriend, with whom he has a money-based relationship and who leads a dubious life, is appropriately called Selina Street.

\section{Defamiliarization through metafiction}

Self-referential elements are also important in Money and they contribute to the distancing effect, by defamiliarizing what is commonly and traditionally accepted in fiction. Besides the term metafictional, various other terms have often been used to refer to these works - selfreferential, narcissistic, or involuted. Even though there might be (slight) differences between them, here they are used interchangeably, the purpose of the paper not being to focus and elaborate on these differences. What all these terms have in common is that they describe fictional works which direct attention to themselves and lay bare the techniques of prose writing. They break down the illusion of reality, an illusion that has been at the core of realist literature, and draw attention to the fictionality of the literary text, thereby inevitably contributing to the distancing and defamiliarization effect Brecht and Shklovsky considered as the raison d'être of art. Several critics have noticed the metafictional in Martin Amis's works and have pointed that his writing is "self-reflective and narcissistic" (Todd 34) and that he "emphasize[s] the fact of fiction via involution" (Alexander 585). In Money what is defamiliarized is both the (natural) relationship between the author and his text and that between the readers and the text. We are time and again reminded that this is a text and the characters in it are fictional. 
Verisimilitude has been the hallmark of realist literature and the test of the realists' artistic achievement has been their ability to create a world that is lifelike. The effect that this kind of fiction has on readers is one of naturalness, a fiction that, as it were, lulls the readers into believing that they are really witnessing (a portion of) the real world. Readers become so engrossed in what they read that they often experience an illusion of real life. Self-referential prose breaks this easy and smooth harmony between words and the world and it destroys the naturalness of the realist or naturalist fiction. It is disruptive and turns inwards by questioning the concept of art as a mirror held up to nature and undermines the concept of verisimilitude. By defying this correspondence, it calls into question the very concept of fiction and puts to test the limits and the potential of fiction. Consequently, metafiction also contributes strongly in creating a defamiliarization effect in readers. By doubting the ability of the text to represent a world out there and by highlighting the fictionality of the text, metafictional prose shakes the readers out of the lulling effect and the naturalness that they have been accustomed to by the novelistic tradition. The defamiliarization effected is not merely a question of presenting to readers an alienated world (in the manner of Sartre or Camus), but rather by alienating them from the way they have been taught to understand the world through fiction and literature in general. Thus what is defamiliarized in a metafictional work is not an object, situation, or a character, but rather the whole concept of fictionality. The reader is forced to reconsider what he has to expect when reading a novel. His habitual expectations are thwarted and disrupted and he is confronted with a work that does not follow the rules of conventional fiction writing but has become unfamiliar and strange.

Even though the metafictional techniques in Money might not be as radical as those in the novels of Vladimir Nabokov, John Barth, or other American metafictional novelists, the self-referential elements are however ubiquitous. By putting into question the whole idea of fictionality and prose writing, these elements also serve to create a defamiliarization effect in the novel. The role of the writer and the relationship they have with their own work is a key consideration in Money. Martin Amis is a character in the novel's plot by becoming the scriptwriter of John Self's movie. Self manages to draw Amis into his own project and then gradually Amis takes over the writing of the script, after the previous writer had failed to produce a feasible movie script. Though the fictional Martin Amis is hired to write the script, he will also help John Self, as well as the readers, to make sense of the puzzles in Self's life and, ultimately, of the whole novel. In an interview with lan McEwan, 
Amis asserts that "I have a godlike relationship [with] the world I've created [...] There is creation and resolution, and it's all up to [me]" (qtd. in Alexander 582). Alexander has argued that by including the writer in the novel, Amis is discouraging the "reader's willing suspension of disbelief," and at the same time encouraging "his awe of the artistwriter" (585). While agreeing with the idea that Amis is discouraging the reader's suspension of disbelief, it is however questionable whether he is encouraging the reader's awe of the artist-writer. It might be argued that, even perhaps unintentionally, Amis is doing precisely the opposite. By laying bare the mechanisms of fiction-writing and by drawing attention to its being a fictional construct, the metafictional writer reveals to the readers that writers are not divinely inspired geniuses, but rather expert craftsmen who manipulate their material, an idea which originates with the Neoclassical writers and theorists.

Even though it is the most prominent metafictional element, the inclusion of the author as a character in his novel is only one of these devices in Money. Amis the author often peeps over and gives some kind of commentary through Self's words and at times it seems as if he is circumventing the protagonist and is addressing directly the readers. Thus, Self is at ease with his life and feels he belongs to the 1980s: "Yesterday afternoon I was doing then what I'm doing now. It's one of my favourite activities [...] I was lying on the bed and drinking cocktails and watching television, all at the same time" (31). However, the author makes himself felt when Self goes on to say: "Television is cretinizing me [...] Soon I'll be like the TV artists. You know the people I mean. Girls who subliminally model themselves on kid-show presenters [...] Men whose manners show newscaster interference, soap stains, film smears" (31). The language in this passage and in several others uttered by Self seem too sophisticated for such an uncouth and uncultured character and contains an undeniable note of social criticism directed at many aspects of contemporary Western civilization, in this case television and its influence. In other passages Amis discusses the status or genre of the novel he has written through Self's words: "London is full of short stories, long stories, epics, farces, sit-coms, sagas, soaps and squibs, walking round hand in hand. And what am I starring in? It feels like slapstick to me. Pornographic slapstick" (238).

The incorporation of Amis in the novel - not in itself a novel device, considering that in English literature it might be traced as far back as Chaucer's Canterbury Tales, with the discrepancy between Chaucer the author and Chaucer the narrator/pilgrim - forces the reader to re-evaluate the concept of the author and his work. When talking about the metafictional novel, Hutcheon writes that "the narrator- 
novelist has, from the start, unrealistically entered his own novel, drawing his reader into his fictional universe" and that "the novel increasingly took this image as a thing in itself worthy of literary treatment: the novelist and his novel itself became legitimate subject matter" (9). The conventional concept of the author as a supreme being who stands apart from his own work, omnipresent though never visible, is questioned and subverted. As a result, the relationship between author and work is viewed from a defamiliarized perspective. The selfreferential element of the author's insertion in the novel serves to highlight the fact that Amis wants readers to acknowledge that what they are reading is not real life but rather a fictitious literary work, since metafictional writing is "writing which consistently displays its conventionality, which explicitly and overtly lays bare its condition of artifice" (Waugh 2, 4). Metafictional writing very well serves the function of e(n)stranging, of turning everything that is settled, accepted and conventional upside down, of upsetting the conventions and the established rules. That is how Martin Amis the character explains to the nonplussed John Self the reasons for Fielding Goodney not walking away and getting away with his scheme when he had the chance: "Because he was hooked. On the fiction, the art. He wanted to get to the end. We all do. A failed actor, he wanted an actor's revenge. He took it out on real life" (347). Amis here might as well be referring to his own metafictional method in Money, in which the author is "taking it out on real life" and creating a literary work which is self-enclosed, self-referential and whose representational status is indeterminate. Money is a novel in which Amis has exposed the convention of the author's role in the writing process by revealing to readers the mechanisms of fiction writing and, often, the difficulties a writer encounters in the artistic process. At one point, for instance, towards the final chapters of the novel, Amis through Self - voices his concern about keeping readers' interest in his novel: "Towards the end of a novel you get a floppy feeling. It may just be tiredness at turning the pages. People read so fast - to get to the end, to be shot of you [...] For how long do you immerse yourselves in other lives? Five minutes, but not five hours. It's a real effort" (331). Metafictional novels, like Martin Amis's Money, "reject the traditional figure of the author as a transcendental imagination fabricating, through an ultimately monologic discourse, structures of order [...] They show [...] that the 'author' is a concept produced through previous and existing literary and social texts" (Waugh 16).

With Amis this dethronement of the author figure often takes the form of parody, even, arguably, of auto-irony. In this novel the story is told from John Self's point of view who is often at odds with the 
author. His comments and views on Martin Amis (the fictional character) are among the most amusing passages. This is what Self says about Amis's house:

I tell you, this Martin Amis, he lives like a student. I had inspected his flat [...] mindful of outlay and lifestyle [...] And there was nothing, no tape recorders or filing cabinets or electric typewriters or word processors [...] Just biros, pads, pencils [...] And he earns enough. Why isn't he living right up to the hilt of his dough? He must have a bad book-habit, this character. (220)

Self is also scandalized by the amount of money they have to pay Martin Amis so that the writer should accept the writing of the script. In line with the comical and parodic mood of the book, in these passages Amis the (flesh-and-bone) author is good-humouredly teasing himself. On the other hand, Amis the author often self-referentially comments on his own creation and feels that he has not been fair with Self by giving him too many defects and leading him into quandaries that may be too much for him. In these passages Martin Amis, the author - through the character-writer Martin Amis - debates the question of the responsibility a writer has towards the characters he creates, echoing Pirandello's same concern in his play Six Characters in Search of an Author:

Is there a moral philosophy of fiction? When I create a character and put him or her through certain ordeals, what am I up to morally? Am I accountable. I sometimes feel that -'

[T] he characters have a double innocence. They don't know why they're living through what they're living through. (241)

In Money the illusion of a real world created in the novel by an author who stands as a "god of creation [...] behind or beyond or above" his work (Joyce 166), is at the same time created and exposed as precisely an illusion: "metafictional novels tend to be constructed on the principle of a fundamental and sustained opposition: the construction of a fictional illusion [...] and the laying bare of that illusion" (Waugh 6). Alexander highlights this tension between reality and illusion in Amis's writings by giving a succinct summary: "It is man's natural tendency to fictionalize, to bestow some kind of order [...] but he should not deny the false truth of the narrative he creates" (581). She sees in Amis a mixture of the aesthetic and moral principle, influenced respectively by two writers he greatly admired, Vladimir Nabokov and Saul Bellow. 
Amis creates a plot about the protagonist, John Self, who is trying to produce his first movie by following the conventional way of creating a plot - exposition, crises and denouement - but at the same time he is revealing to readers that he is constructing a literary work by questioning the very use of these elements of plot construction. In Money he both uses and subverts these elements. One of the most striking self-referential fragments in the novel, narrated by Self, is the game of chess that he and Amis play towards the end of the novel, a game the moves of which somehow encapsulate Self's own history in Money, in which he gradually is cheated of all his money and left penniless:

I was searching for blueprints, for forms and patterns, when he launched into a tedious series of pokes and prods at my extended pawns [...] Within the space of three moves I had been nudged into a position of intricate inertia, my pieces cramped and clustered, misled, cross-purposed. It would take at least two tempos to find any freedom and I never seemed to have a beat to spare. (344)

The whole game closely parallels the way Self was gradually manipulated in a position where he could no longer escape by Goodney's well-calculated moves and by his own thoughtlessness and self-confidence. Self loses the game to Amis just like he has lost everything in his game to Goodney. In the last pages, when everything is cleared up and Self - and the readers - have been shown the truth behind Goodney's (and Amis's) elaborate scheme, Self says that he doesn't "see Martin Amis any more because [he] owes him money, in a sense [...] I once thought he and I might be friends. But there's nothing between us, now that there's no money between us" (358). The word "money" here has multiple meanings. It first refers to the fact that being now penniless, Self cannot afford to pay the fictional Martin Amis for his scriptwriting; however, it also self-referentially refers to the novel's title. He owes Martin Amis his being the protagonist of the book, but now that the novel (Money: A Suicide Note) is over, there's nothing between them anymore.

Most of the names that Amis has used in the book are also selfreferential. The protagonist's name, John Self, fits in perfectly with the novel's self-referentiality. All events somehow relate to him and in the course of the story he will find out the truth about his business venture and about his biological father. Self is a narcissistic character who somehow mirrors the narcissistic (self-referential) elements in the novel. The names of other characters also metafictionally foreground 
the fictionality of the novel and refer to the author himself. Thus the two (arguably positive) characters who assist Self in making sense of the plot of his life and of the novel are Martin Amis the character and Martina Twain, whose name obviously also self-referentially relates to the author. Both Martin and Martina from time to time try to open Self's eyes to the precariousness of his position and the possibility that his producer is purposefully misleading him, even though Self takes no heed until it is too late and all of his money has been drained.

Amis even discusses the responsibilities that an author has towards the characters he creates in a conversation with Self (already cited above). Metafictionally, he is describing the distance he as a writer from the very start has created with John Self by portraying him as "wicked, deluded, pitiful or ridiculous" and that "[ $t$ ] he further down the scale he is, the more liberties you can take with him. ... This creates an appetite for punishment. The author is not free of sadistic impulses" (229). These words are lost on John Self who lacks the necessary education and sophistication to interest himself in a conversation about aesthetics and ethics. Through them Amis is commenting both on his work as a writer and on the situation of the protagonist in his book. Self is indeed a character situated "down the scale" and Amis has "taken more liberties" with him. He has created a protagonist who is shallow, insensitive and inconsiderate. Richard Todd, focusing on the doubles in Amis's work, has noted that Self is "exploited" by the doubles in the novel, Martin Amis and Martina Twain and that "he becomes the object rather than the subject of his narration, and is thereby reified" (28). Tamás Bényei too refers to this portrayal of John Self as a sort of "sadism", in which "the readers ... become complicit" (47). Martina Twain as well in her conversation with John Self refers metafictionally to Self's own situation and his position in the novel when, discussing aesthetics with him, she talks "about the vulnerability of a figure unknowingly watched" and that the "analogous distinction in fiction would be that between the conscious and the reluctant narrator-the sad, the unwitting narrator" (126). Through his female voice in Money, Martina Twain, Amis is again referring to his protagonist and the situation he is in. For all his braggadocio, Self is indeed vulnerable, being "unknowingly watched" and he is also an "unwitting narrator", not able to understand his situation, which is reflected in the novel by his frequent blackouts. "I disclaim responsibility for many of my thoughts. They don't come from me" (247), Self confides to the reader, and in another fragment he complains: "I sometimes think I am controlled by someone. Some space invader is invading my inner space [...] But he's not from out there. He's from in here" (305). 


\section{Conclusion}

To a reader who identifies fictional works with depth of psychology and the presentation of round and dynamic characters, such as those of, say, Dostoyevsky or Bellow, characterization in Money might seem deficient and flawed. John Self has caricature-like elements and may be seen as a type character while the novel can be regarded as a satire and parody leveled at modern life, a (Menippean) work very much in the vein of Gulliver's Travels, in which the eponymous protagonist and other characters lack the psychological depth and are subordinated to the author's aim to expose and condemn human vices and contemporary flawed institutions. As in Gulliver's Travels, Amis defamiliarizes many of the things people usually take for granted and he achieves this through parody and self-referentiality. Several things are parodied in Money - the traditional first-person narrator, the authoritative authorial voice, the (post)modern ethos of consumerism, opportunism, television, and marketing. Often the parody in Money even verges on caricature, in which grotesque characters populate a grotesque world and that adds to the defamiliarization effect of the novel. Readers are presented with a protagonist who is unlikable violent, uncouth, uncultured, addicted to pornography and alcohol, a typical yob. Due to his grossness and coarse manners, the character is defamiliarized and the reader finds it difficult, if not outright impossible, to identify with him.

As shown in the second part of the article, another way of achieving defamiliarization in Money is through the metafictional techniques. Money foregrounds its own fictionality and fiction writing becomes itself its content and focus, thereby disrupting the familiar identification of readers with the protagonist, and following Shklovsky's idea that "[a]rt is a means of experiencing the process of creativity" (Shklovsky6). By turning himself into a character in the novel, who takes over the writing of Self's novel, Amis engages the reader into the aesthetic as well as ethic problems of fiction writing and the writer's (as well as the reader's) responsibility. Money, and generally novels containing self-referential elements, has often been accused of its inability to create "living characters, humanity, maturity, seriousness, unity" and of ignoring the human concerns and the outside reality. Money is indeed filled with references to its own plot and to the problematic of fiction writing and it directs the readers to the writing process and the relationship between the author and their own text. Self-referential novels shift the focus of representation away from the outside world of objects or the inside world of the mind towards the process of writing and fiction itself. Thus, "[r]epresentation is [...] turned 
in on itself, and the 'narration' invades and pervades the 'fiction'" (Hutcheon 35). On the other hand, no matter how involuted and selfabsorbed this (or any) novel might be, it also refers to a world outside and cannot, altogether, break its ties with the reality and the most fundamental topics of that reality. In this respect, Martin Amis's works present an interesting dualism between a playfulness and exuberance of style and a seriousness of themes explored in them.

In spite of its self-referentiality, Money nonetheless is concerned with such matters as individual responsibility in the modern, ever-changing, world and the need for sympathy and human bonding. It also offers a critique of the (post)modern world, especially people's acquisitive tendency and money, which the author regards as "the central deformity in life [...] one of the evils that has cheerfully survived identification as an evil" (Interview with Haffenden, qtd. in Tredell 63). Furthermore, it might be argued that Money and other self-referential works point out precisely the fact that a literary work is an artificial construct by breaking the illusion that literature represents reality. The familiar and natural relationship between reality and literary text and that between the author and their work is defamiliarized. Amis achieves defamiliarization through parody, the comical perspective, and the metafictional devices that question the very status of a literary work. Even though to readers whose expectations are based on conventional assumptions this laying bare and defamiliarization might seem as detrimental to fiction, what this method ultimately aims at is engaging the reader more actively in the reading process, turning them into active readers, since they "too have something of the authorial power to create life" (Amis 242). Once the writers openly reveal to them the mechanisms of the creative process - which are concealed by conventional fiction that aims at creating an illusion of reality - the readers become themselves co-creators and become more involved in the construction of meaning.

\section{Works Cited}

Alexander, Victoria. "Between the Influences of Bellow and Nabokov." The Antioch Review 52.4 (1994): 580-590.

JSTOR, http://www.jstor.org/stable/4613033.Web. 01 Dec. 2020.

Amis, Martin. Money. London: Penguin Books, 1986. Print.

Bényei, Tamás. "The Passion of John Self: Allegory, Economy, and Expenditure in Martin Amis's Money." Martin Amis: Postmodernism and Beyond. Ed. Gavin Keulks. New York: Palgrave Macmillan, 2006. 36-54. Print.

Coleridge. Samuel T. Biographia Literaria. Chap. XIV. Project Gutenberg, https://www.gutenberg.org/files/6081/6081-h/6081-h.htm.Web. 15 Nov. 2020. 
Crews, Brian. "Martin Amis and the Postmodern Grotesque." The Modern Language Review, 105.3 (2010): 641-659.

JSTOR, http://www.jstor.org/stable/25698800.Web. 10 Dec. 2020.

Finney, Brian. "Narrative and Narrated Homicides in Martin Amis's Other People and London Fields." Critique: Studies in Contemporary Fiction, 37.1 (1995): 3-15. Print.

Hutcheon, Linda. Narcissistic Narrative: The Metafictional Paradox. Ontario: Wilfrid Laurier University P, 1980. Print.

Joyce, James. A Portrait of the Artist as a Young Man. Hertfordshire: Wordsworth Editions, 1997. Print.

Ryan, Kiernan. "Sex, Violence and Complicity: Martin Amis and Ian McEwan." An Introduction to Contemporary Fiction. Ed. Rod Mengham. Cambridge: Polity, 1999. 203-18. Print.

Lewis, Barry. "Postmodernism and Literature." Routledge Companion to Postmodernism. Ed. Stuart Sim. London: Routledge, 2001. Print.

Mills, Sara. "Working with sexism: What can feminist text analysis do?" Twentieth-Century Fiction: From Text to Context. Ed. Peter Verdonk and Jean Jacques Weber. London: Routledge, 1995. 206-219. Print.

Parker, Emma. "Money Makes the Man: Gender and Sexuality in Martin Amis's Money." Martin Amis: Postmodernism and Beyond. Ed. Gavin Keulks. Hampshire: Palgrave Macmillan, 2006. 55-70. Print.

Sher, Benjamin. "Shklovsky and the Revolution", Translator's Introduction. Viktor Shklovsky. Theory of Prose. Trans. Benjamin Sher. Elmwood Park, Illinois: Dalkey Archive Press, 1991. Xv-xxi. Print.

Shklovsky, Viktor. "Art as Device." Theory of Prose. Trans. Benjamin Sher. Elmwood Park, Illinois: Dalkey Archive Press, 1991. 1-14. Print.

Sutherland, John. "Making Strange," London Review of Books, 3.5 (1981):21. Https://www.Irb.co.uk/the-paper/v03/n05/john-sutherland/makingstrange. Web. 27 Apr. 2021.

Todd, Richard. "Looking-glass Worlds in Martin Amis's Early Fiction: Reflectiveness, Mirror Narcissism, and Doubles." Martin Amis: Postmodernism and Beyond. Ed. Gavin Keulks. Hampshire: Palgrave Macmillan, 2006. 22-35. Print.

Tredell, Nicolas, editor. The Fiction of Martin Amis. Hampshire: Palgrave Macmillan, 2000. Print.

Waugh, Patricia. Metafiction: The Theory and Practice of Self-Conscious Fiction. London: Routledge, 1984. Print.

Wordsworth, William. "Preface to Lyrical Ballads." The Oxford Anthology of English Literature. Romantic Poetry and Prose. Ed. Harold Bloom and Lionel Trilling. New York: Oxford University P, 1973. 592-611. Print. 


\section{PARODIA DHE METAFIKSIONI SI MJETE DEFAMILJARIZIMI NË ROMANIN E MARTIN EJMISIT, PARAJA: LETËR VETËVRASJEJE}

Artikulli trajton mënyrën se si realizohet defamiljarizimi në romanin e Martin Ejmisit, Paraja: Letër vetëvrasjeje (Money: A Suicide Note, 1984), nëpërmjet parodisë, perspectives komike dhe elementeve metafiksionale. Në hyrje shpjegohet shkurtimisht koncepti i defamiljarizimit, kurse në pjesën e pare përshkruhet se si përdoret parodia në këtë roman. Ky libër parodizon një sërë teknikash letrare dhe, në të njëjtën kohë, është edhe parodi e kritikë e Britanisë dhe e Amerikës së viteve '80, veçanërisht konsumerizmit të këtyre viteve. Nëpërmjet perspectives komike, Ejmisi krijon një distancim ndërmjet vetes si autor dhe protagonistit të romanit, Xhon Selfit. Ai është një rrëfimtar, të cilit nuk mund $t^{\prime} i$ besohet dhe për të cilin lexuesi nuk ndien simpati. Shpeshherë personazhi i Selfit afron me grotesken, çka e thekson edhe më tepër defamiljarizimin në roman. Edhe elementet metafiksionale, të cilat diskutohen në pjesën e dytë, janë me rëndësi dhe ndikojnë në efektin e distancimit, duke defamiljarizuar çka pritet zakonisht nga një vepër letrare artistike. Një prej elementeve më të rëndësishme metafiksionale (ose vetë-referuese) është përfshirja e autorit si një personazh në roman. Kjo teknikë e nxit lexuesin që ta vështrojë nga një këndvështrim i ri marrëdhënien që ka autori me veprën e vet, marrëdhënie që tani shihet nga një perspektivë e defamiljarizuar.

Fjalë kyçe: defamiljarizim, distancim, metafiksion, parodi, groteske, konsumerizëm, etikë 